ingly numerous in southern Iraq, especially in Basra province. Vegetable cultivation is widespread, main varieties being melons, tomatoes, cucumbers and egg plants ; but there is unfortunately a prejudice against vegetable cultivation in certain provinces, notably Amarah and Muntafiq, where the vegetable farmers are regarded as socially inferior to those growing the bread grains.

Main crops are barley $(12,100 \mathrm{sq} . \mathrm{km}$.), wheat $(10,460 \mathrm{sq} . \mathrm{km}$.$) and rice (1,287 \mathrm{sq} . \mathrm{km}$. $)$. The most important industrial crops are cotton $(24,100$ hectares) and tobacco $(10,200$ hectares $)$, the latter being grown almost exclusively in the northern provinces of Sulaimaniyah, Mosul and Arbil.

Share-cropping is general, and there is a great weight of agricultural debt. Co-operation has made exceedingly slow progress; but efforts are now being made, with the assistance of foreign experts, to develop various forms of co-operation, to promote rural industries and to introduce facilities for 'fundamental education'.

\section{SEED PRODUCTION, TESTING AND DISTRIBUTION IN EUROPEAN COUNTRIES}

$\mathrm{T}$

THE Food and Agriculture Committee of the Organization for European Economic Cooperation has published a report on an important aspect of agricultural production in eleven of the eighteen member countries which pledged themselves by signing in 1948 the convention for European Economic Co-operation. The report by Technical Assistance Mission No. 106 on "Seed Production, Testing and Distribution in European Countries"* is one of a series of reports the purpose of which is that of "increasing European agricultural production on the most efficient lines", and no one can pretend, even in the eleven countries participating-Austria, Belgium, Denmark, France, Germany, Ireland, Italy, Netherlands, Norway, Sweden and the United Kingdom-that agriculture has reached a state of technical perfection. In spite of there being an apparent economic surplus of some primary products of agriculture-particularly cereal grains - at the moment, and although certain governments appear to be endeavouring to control production to stabilize prices, the world is still short of food.

In the present circumstances, therefore, this report is interesting and significant not only because of its origin, but also because of its content and its implications. Not only must there be a continuous increase in the amount of food produced, but there must also be improved efficiency in production and greater attention to quality. Although there is still not sufficient food being produced in the world to feed everyone adequately, there is, in countries with the highest standards of living, a growing concern over the increasing cost of food and a more discriminating awareness of the difference between good and poor quality. There is therefore every inducement for farmers to do everything to lower costs of production and concentrate on producing articles of acceptable quality. The recent experience of the agitation caused by the operation of a 'free market' for cereals in Britain bears out this contention.

* Seed Production, Testing and Distribution in European Countries. Technical Assistance Míssion No. 106. Pp. $166+4$ annexes. (Paris: O.R.E.C., 1954.)
The Food and Agriculture Committee is therefore wise in linking efficiency of production to total production, and in the present context this is recognized in the attention that has been paid in this report to the importance of seed production, testing, distribution and crop improvement as means of improving crop production in terms of quantity, quality and efficiency. The Mission responsible for the report concludes from its survey that all the countries it visited could benefit by the adoption of certain of its recommendations, and it has not hesitated to mention matters for government consideration in individual countries concerning seed legislation and regulations, seed production, and crop improvement by plant breeding.

It is only to be expected that each of the countries visited had its own particular problems and ways of dealing with these problems; but it is, nevertheless, surprising how each country reflected such different emphasis on the similar matters relating to organization, legislation and research. It is therefore not surprising that the Mission found reason to criticize and to remark upon the uneven standard between the countries, while concluding that co-ordination and co-operation between countries would confer considerable benefits. This is significant when it is realized that the countries visited have among them the most intensive and highly productive agricultures in the world, with highly organized agricultural services, commercial organizations and research.

The general impression left by the report is that much could be done to improve the position by individual national effort and by. international co-operation. It is recognized by the authors that agriculture cannot reach its highest state of efficiency without an adequate supply of the best seeds for crop production, but the organization and technical efficiency do not always exist to provide this seed. In this context, it is proposed that improvements would result from better co-ordinated and more uniform crop-variety trials, while the inadequacy of such trials with certain crops in some countries is criticized. It was felt also that international action on plant quarantine regulations is desirable, while concern is expressed at the confused nomenclature in use for describing the various categories of certified seed sold in various countries. Finally, the importance of plant breeding in providing improved varieties is stressed, although it is pointed out that this is not generally recognized in all countries. Indeed, the comments on the organization and development of plant-breeding research indicate that there is much to be done to raise the general position throughout the countries visited to a satisfactory lovel.

\section{VANADATE GLASSES}

\section{By E. P. DENTON, H. RAWSON and J. E. STANWORTH}

Research Laboratory, The British Thomson-Houston Co., Ltd., Rugby

$T$

HERE has been some doubt as to the extent to which vanadium pentoxide can be regarded as a 'glass-forming' oxide, that is, as an oxide which can promote glass formation from melts containing no other recognized glass-forming oxide such as those 